\title{
TANDA-TANDA DALAM IKLAN KOMERSIAL DI TELEVISI (ANALISIS SEMIOTIKA PADA IKLAN SUSU SGM EKSPLOR PRESINUTRI 3)
}

\author{
Erni Herawati ${ }^{1}$; Rosidah $^{2}$ \\ Marketing Communication Department, Fakulty of Economic and Communication, BINUS University \\ Jl. K. H. Syahdan No. 9, Kemanggisan - Palmerah, Jakarta Barat 11480 \\ 1er_ha08@yahoo.com; ${ }^{2}$ ochid35@gmail.com
}

\begin{abstract}
Advertisement is one of promotional tools used by marketer to communicate with its audience or consumer which can be done through newspaper, magazine, internet, radio, and/or television. Using advertisement, the marketer tries to create signs in the message to the audience to make sure they really understand the message. The objective of the study is to analyze how the signs are created in the texts displayed on infant formula SGM Eksplor Presinutri 3 TV advertisement. The metodology is qualitative research using semiotics analysis. Peirce semiotics approach is applied to explore the signs in the advertisement. Secondary data were used, also supported by study literature, to conduct a deep analysis of this study. The research finding shows signs were used by the marketer to deliver the message of this product.
\end{abstract}

Keywords: TV advertisement, semiotics analysis, infant formula advertisement

\begin{abstract}
ABSTRAK
Iklan merupakan suatu media komunikasi antara pemasar dengan konsumennya yang dapat dilakukan melalui berbagai media seperti koran, majalah, internet, radio dan/atau televisi. Di dalam iklan pemasar berusaha untuk menciptakan tanda dalam pesan yang ingin disampaikan kepada konsumen agar mereka dapat betul-betul memahami pesan tersebut. Penelitian ini bertujuan untuk menganalisa bagaimana tanda-tanda yang terdapat dalam teks-teks yang ditampilkan dalam iklan susu formula SGM Eksplor Presinutri 3 di televisi. Metodologi yang digunakan adalah kualitatif dengan pendekatan analisis semiotika. Pendekatan semiotika Peirce digunakan oleh peneliti untuk mengungkap tanda-tanda dalam iklan tersebut. Data sekunder yang luas dan studi kepustakaan dilakukan untuk melakukan analisa yang mendalam untuk mengungkap tujuan penelitian. Dari analisa tersebut dapat diungkapkan tanda-tanda yang relevan dengan pesan yang ingin disampaikan oleh pemasar.
\end{abstract}

Kata kunci : iklan televisi, analisis semiotika, iklan susu formula 


\section{PENDAHULUAN}

Iklan merupakan pemusatan penciptaan dan pengelolaan terhadap makna-makna yang lebih luas (Hackley, 2005: 1). Banyak sekali simbol yang diciptakan oleh iklan untuk dapat dimaknai oleh para pembaca iklan. Holmes (2005) mengatakan bahwa salah satu fungsi dari teks yang ada dalam iklan ada pada sejumlah hubungan yang terdapat pada pembaca iklan dan teks itu sendiri. Antara pengiklan dan pembaca iklan, mereka tidak bertemu secara fisik, tetapi berinteraksi lewat iklan. Sejalan dengan pandangan Holmes, dalam hubungan yang melingkupi teks, komoditas dan iklan tertentu, memilih dan menciptakan konteks yang spesifik seperti memilih bahan seperti usia, gender, lokasi, pendapatan, pendidikan, faktor bahasa dan lainnya untuk membentuk perpaduan tertentu. Dengan demikian pengiklan dapat menargetkan pembaca iklan yang merepresentasikan karakteristik dari kelompok yang disasar. Komunikasi akan dianggap sukses apabila pengiklan menggunakan "common knowledge".

Keberadaan iklan dalam media audio visual dengan media yang lain tentu punya efek yang berbeda. Televisi merupakan media yang komplet karena dapat memuat pesan dalam bentuk audio dan visual dengan moving image. Iklan-iklan komersial akan lebih mempunyai daya jual bila berhasil memanfaatkan keunggulan yang dimiliki oleh media televisi tersebut. Pemasang iklan harus benarbenar bisa memetakan kepada siapa iklan tersebut akan ditujukan, sehingga tujuan dari penjualan barang akan tercapai. Studi mengenai penyasaran khalayak televisi juga pernah dilakukan oleh Fiske (dalam Denzin \& Lincoln, 2009: 240-241), dimana televisi jaringan FOX milik Rupert Murdoch yang menjadikan remaja belasan tahun dan dewasa muda yang belum berkeluarga menjadi target sasaran acara-acara televisi yang ditayangkan di jaringan tersebut. Acara televisi, yaitu The Simpson dan Married...with Children yang ditayangkannya telah menimbulkan kecemasan sosial tersendiri, karena beberapa materi yang sifatnya kontroversial yang digabungkan dengan fakta bahwa remaja belasan tahun tersebut telah menjadi pemirsa yang dapat dijual kepada pengiklan. Dari sini dapat diambil kesimpulan bahwa segmentasi pasar dari acara dan iklan di televisi adalah menjadi perhatian utama dari pengiklan. Definisi "pemirsa” bergantung pada cara penempatannya dalam tatanan sosial. Ketika ditempatkan dalam sistem ekonomi, pemirsa menjadi segmen pasar yang harus dijangkau dan juga menjadi komoditas yang diperjualbelikan (dalam Denzin \& Lincoln, 2009: 245).

Dalam pandangan Bungin (2006: 221) teknologi terutama televisi, sistem teknologi, telah menguasai jalan pikiran masyarakat dimana televisi telah membangun teater dalam pikiran manusia (theater of mind) dengan gambaran realitas iklan televisi. Pembentukan budaya telah dilakukan oleh tayangan-tayangan televisi termasuk iklan. Menurut Fiske (dalam Denzin \& Lincoln, 2009: 245) kebudayaan merupakan perputaran makna, kesenangan, dan nilai secara sosial. Kebudayaan itu sendiri dapat menciptakan tatanan sosial dan membantu melestarikan serta mengukuhkannya atau bisa didobrak dan diubah, tetapi pada dasarnya budaya tidak pernah netral. Selanjutnya Fiske juga menyebutkan bahwa tindakan audiensi (menonton televisi) merupakan tindakan diam-diam yang merupakan sebuah praktik untuk memproduksi makna bukan benda, yang hadir sebagai sebuah proses bukan produk sehingga sering lolos dari perhatian kita (dalam Denzin \& Lincoln, 2009: 251).

\section{Permasalahan}

Pengiklan harus bisa mendapatkan perhatian pemirsa (audience) yang biasanya tidak tertarik pada iklan; bagaimana pesan tersebut disampaikan sama pentingnya dengan apa yang dipesankan (Straubhaar \& La Rose, 2004: 350). Sejalan dengan kepentingan pemasaran produk, maka realitas yang dibentuk oleh pembuat iklan membuat mereka mengarahkan makna-makna yang akan ditangkap oleh pembaca iklan dengan membuat tanda-tanda yang diinginkan. Dalam iklan susu untuk anak, maka tanda-tanda dalam teks yang terdapat dalam iklan tersebut sering kali memasukkan faktor meminum susu sebagai bagian utama dalam tumbuh kembang anak. Studi ini memfokuskan penelitian 
pada iklan susu formula SGM Eksplor Presinutri 3 sebagai objek dalam penelitian. Permasalahan yang diangkat disini adalah seperti apa tanda-tanda yang terdapat dalam teks-teks yang ditampilkan dalam iklan susu formula SGM Eksplor Presinutri 3 yang ditayangkan di televisi.

\section{Tujuan Penelitian}

Tujuan dari dilakukannya penelitian ini secara khusus adalah untuk tanda-tanda yang terdapat dalam teks-teks yang ditampilkan dalam iklan susu formula SGM Eksplor Presinutri 3 yang ditayangkan di televisi. Tanda-tanda di sini termasuk dialog, pengaturan warna dalam keseluruhan iklan, tulisan dan keterangan yang muncul, serta setting adegan. Sedang tujuan secara umum adalah untuk mengetahui konsep-konsep semiotika diterapkan dalam dunia periklanan media massa.

\section{Advertising Appeals dalam Iklan}

Suatu iklan harus dibuat semenarik mungkin agar mendapat perhatian dari konsumen. Oleh karena itu, biasanya pemasar menggunakan pendekatan tertentu atau yang biasa disebut 'appeal' (advertising appeal). Appeal dapat dipandang sebagai cara untuk menggerakkan konsumen, berbicara untuk memenuhi kebutuhan atau keinginan mereka, dan juga untuk menarik minat konsumen (Belch \& Belch, 2009: 283). Menurut Belch \& Belch (2009: 283), secara garis besar advertising appeal dibagi dua bagian, yaitu Informational/Rational appeals dan Emotional appeals.

Lebih lanjut dikatakan oleh sumber yang sama bahwa Informational/Rational appeals berfokus kepada kebutuhan praktis konsumen, kebutuhan fungsional atau kebutuhan yang bersifat utilitarian, terhadap suatu barang atau jasa dan menekankan pada fitur barang atau jasa tersebut dan/atau manfaat atau alasan untuk memiliki atau menggunakan merek tertentu. Isi dari suatu iklan yang menggunakan Informational/Rational appeals menekankan pada fakta, proses pembelajaran, dan logika. Weilbacher (dalam Belch \& Belch, 2009: 284) mengatakan bahwa beberapa jenis advertising appeal yang masuk dalam kategori Rational appeal adalah dengan memperlihatkan fitur, competitive advantage, harga yang menarik, berita (news), dan kepopuleran barang atau jasa.

Kategori advertising appeal yang lain adalah Emotional appeals, dimana hal ini berkaitan dengan kebutuhan sosial dan/atau psikologis untuk membeli suatu barang atau jasa. Banyak juga konsumen yang memutuskan untuk membeli atau menggunakan barang atau jasa berdasarkan perasaan dibandingkan pengetahuan mereka akan fitur atau atribut barang atau jasa tersebut. Belch \& Belch (2009: 285) mengatakan bahwa banyak jenis perasaan atau kebutuhan yang dapat menjadi dasar advertising appeals yang didesain untuk memengaruhi konsumen pada tingkat emosional mereka. Appeals tersebut adalah keselamatan, keamanan, ketakutan, cinta, kasih sayang, kebahagiaan, kegembiraan, nostalgia, sentimen, kegairahan, rangsangan, kesedihan/duka, kebanggaan, pencapaian/prestasi, penghargaan diri (self-esteem), aktualisasi diri, kesenangan, ambisi, kenyamanan; dimana jenis perasaan-perasaan tersebut didasarkan pada keadaan psikologis atau perasaan tentang diri sendiri. Ada lagi jenis perasaan yang berdasarkan rasa sosial atau berbasis sosial, seperti pengakuan (recognition), status, menghormati, keterlibatan, hal yang memalukan, afiliasi/pemilikan, penolakan, penerimaan, dan persetujuan.

Para marketer atau komunikator dapat menggunakan emotional appeals dalam menciptakan desain kreatif pada iklan mereka, terutama untuk memperlihatkan bagaimana karakter dalam iklan tersebut mendapatkan hasil atau manfaat secara emosional dari merek barang atau jasa yang mereka tawarkan. Diharapkan dengan penggunaan emotional appeals ini perasaan positif yang dibangkitkan dapat ditransfer kepada merek barang atau jasa perusahaan tersebut. Sebuah penelitian menunjukkan bahwa keadaan suasana hati atau perasaan positif yang ditampilkan dalam suatu iklan dapat memberikan efek yang menyenangkan (baik) pada evaluasi konsumen terhadap suatu merek (Belch \& Belch, 2009: 285). Penelitian lain juga membuktikan bahwa iklan yang mengandung pesan emosional 
lebih mudah diingat daripada iklan yang pesannya tidak mengandung unsur emosional (Belch \& Belch, 2009: 286).

Selain itu, untuk mendapatkan hasil yang lebih efektif, para marketer atau komunikator dapat juga mengkombinasikan penggunaan rational dan emotional appeals dalam iklan yang mereka ciptakan. Hal ini dikarenakan seringnya keputusan membeli para konsumen didasarkan oleh kedua hal tersebut, motif rasional, dan emosional.

\section{Semiotika Peirce}

Semiotika adalah sebuah ilmu tentang tanda (Segers, 2000: 4-5, dalam Sobur, 2003: 7). Menurut Saussure, Semiologi adalah ilmu yang mengkaji tentang tanda-tanda yang ada di tengah masyarakat dengan tujuan untuk menunjukkan bagaimana terbentuknya tanda-tanda beserta aturanaturannya (Budiman, 1999: 107 dalam Sobur, 2003: 12). Makna diperoleh dari pemahaman terhadap budaya dan konstruk-konstruk sosial dan bukan dari refleksi diri pribadi terhadap diri lain (Mead, 1934 dalam Denzin \& Lincoln, 2009: 623).

Bagi Peirce, tanda adalah sesuatu yang dengan mengetahuinya kita akan mengetahui sesuatu lebih dalam lagi (Johansen \& Larsen, 2002: 25). Berdasarkan Peirce (Johansen \& Larsen, 2002: 26), terdapat tiga elemen yang penting dalam menganalisa tanda yaitu: 1) tanda, sesuatu yang lain yang merepresentasikan hal lain di luar tanda itu sendiri; 2) objek, acuan dari tanda itu sendiri atau sesuatu yang kehadirannya dirujuk oleh suatu tanda; 3) interpretan, makna yang ada dalam benak seseorang tentang objek yang dirujuk oleh sebuah tanda. Hubungan ketiganya dapat digambarkan dalam segitiga berikut.

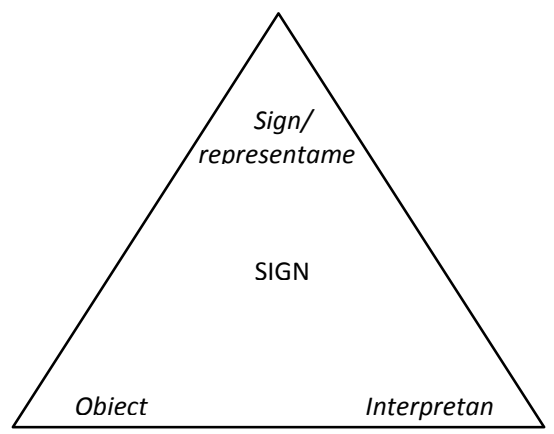

Gambar 1 Tiga Elemen Penting dalam Tanda

Berdasarkan objeknya, Peirce membagi tanda menjadi antara lain: icon, index, dan symbol (Johansen \& Larsen, 2002: 51). Ikon adalah tanda yang menghubungkan antara penanda dan petanda atau antara tanda dan objek acuan. Indeks adalah tanda yang menunjukkan hubungan antara tanda dan petanda yang bersifat kausal atau tanda yang langsung mengacu pada kenyataan. Simbol adalah tanda yang menunjukkan hubungan antara penanda dan petanda berdasarkan konteks masyarakat. Ketiganya mempunyai hubungan yang saling terkait dalam memproduksi makna.

\section{Tanda-Tanda dalam Iklan}

Menurut Sobur (2003: 116) iklan dapat dikaji dengan menggunakan perspektif semiotika yaitu dengan mengkajinya lewat sistem tanda di alam iklan. Sistem tanda dalam iklan terdiri atas lambang nonverbal dan verbal. Lambang verbal berupa bahasa yang kita kenal, sedangkan nonverbal adalah bentuk dan warna yang disajikan dalam iklan. Selain itu, terdapat ikon dalam bentuk warna yang serupa atau mirip dengan keadaan sebenarnya seperti gambar benda, orang, atau binatang yang 
digunakan sebagai lambang. Selanjutnya Sobur juga menyebutkan bahwa kajian iklan juga mencakup objek, yaitu apa yang diiklankan. Dalam iklan produk atau jasa maka produk atau jasa itulah objeknya.

Aspek yang paling penting dalam reklame adalah aspek komersial (Berger, 2005: 29-32). Sejalan yang dikatakan oleh Berger tersebut, bentuk tanda-tanda juga berkaitan dengan objek dan budaya material, seperti pakaian, perhiasan, rumah dan perabotan, dsb. Dalam beberapa kasus bendabenda tersebut memberi kita perasaan atau pesan tertentu. Dan dalam kasus-kasus yang lain bendabenda bisa menginformasikan sesuatu mengenai seseorang, baik disadari atau tidak. Selain itu, kita juga memberikan banyak tanda melalui bahasa tubuh, gerak-gerik yang kita lakukan. Selanjutnya, suara dan musik juga menambah sound effect untuk membangkitkan respon emosional. Suara dan musik memainkan peran sangat penting dalam produksi film dan televisi, yang berfungsi sebagai "isyarat" yang mengindikasikan bagaimana kita harus merespon secara emosional terhadap tindakan atau peristiwa yang diberikan.

Tanda adalah sesuatu yang merepresentasikan atau menggambarkan sesuatu yang lain (di dalam benak seseorang yang memikirkannya). Tanda terdiri dari atas dua materi dasar yakni 'ekspresi' (seperti kata, suara, atau simbol dan sebagainya) dan 'konten’ atau isi (makna atau arti) (Hjemlev, 1961, dalam Denzin \& Lincoln, 2009: 617). Suatu tanda menandakan sesuatu selain dirinya sendiri, dan makna adalah hubungan antara suatu objek atau ide dan suatu tanda (Littlejohn, 1996: 64).

Proses penghubungan atau pemaknaan ekspresi dengan konten bersifat sosial dan sangat bergantung pada perspektif atau cara berpikir sang pengamat. Tanda tidak pernah sepenuhnya 'lengkap' karena memerlukan 'interpretan' atau konteks. Dengan demikian, hanya kontekslah yang dapat menghubungkan ekspresi dengan konten (Manning \& Swan dalam Denzin \& Lincoln, 2009: 618).

Menurut Manning \& Swan (dalam Denzin \& Lincoln, 2009: 622), media cenderung mengaburkan bentuk dan membaurkan kenyataan dengan segala yang bersifat artifisial. Fiksi, berita, dan peristiwa diaduk-aduk dan ditayangkan melalui berbagai macam acara seperti Top Cops, Cops, dan Rescue 911, acara-acara ini memproduksi realitas tapi dalam versi-versi tertentu. Contoh lainnya juga seperti penyatuan iklan dengan berita dan dengan drama. Manning \& Swan juga mengatakan bahwa media turut berperan dalam penyebaran fragmen-fragmen citra yang bersifat atemporal, sureal, dan hidup. Gambar tersebut diasosiasikan dengan berbagai video musik, disisipkan ke dalam berita, melodrama, dan iklan.

Menurut pandangan semiotika strukturalisme, teks dapat bisa dibaca dengan berbagai macam cara. Realitas dikonstruksikan secara sosial. Makna sangat tergantung pada konteks. Makna merupakan salah satu fungsi tindak pengodean (Barthes, 1975, dalam Denzin \& Lincoln, 2009: 621). Setiap teks menyimpan makna. Hanya saja, makna tersebut tidak selalu 'tidak pasti' atau 'tidak definitif'. Makna sebuah teks bisa berubah seiring dengan pergeseran konteks yang melatarinya (Manning \& Swan, dalam Denzin \& Lincoln, 2009: 620).

Menunjuk pada pendapat Berger (2005: 39-42) tanda memiliki variasi aspek visual antara lain: 1) Penggunaan warna, perbedaan warna cenderung menimbulkan perbedaan emosi; 2) Ukuran, ukuran tidak hanya berkaitan dengan dimensi, tetapi juga pada unsur keterkaitan antara tanda dengan sistem tanda; 3) Ruang lingkup, kita dikenalkan dengan hubungan diantara unsur-unsur dalam sistem tanda semacam periklanan. Seperti contoh dalam iklan kosmetik dalam majalah yang memiliki ruang kosong, ruang kosong tersebut merupakan tanda tentang keanggunan kualitas dan selera tinggi; 4) Kontras, diartikan sebagai perbedaan antara elemen-elemen dalam sebuah tanda yang ada dalam istilah-sitilah seperti warna, ukuran, ketajaman, dan tekstur. Kontras juga digunakan untuk memperjelas dan menegaskan oposisi seperti terang-gelap, ruwet-sederhana, dll. Iklan yang ruwet menyodorkan sejumlah besar informasi, namun sukar untuk menegaskan tiap elemen. Sedangkan iklan yang terlalu sederhana tidak akan memuat banyak informasi; 5) Bentuk, memainkan peranan penting 
dalam iklan-iklan, seperti bentuk hati berwarna merah yang melambangkan cinta; 6) Detail, meyarankan kepekatan seperti butiran-butiran pada foto.

\section{Faktor-Faktor yang Memengaruhi Pertumbuhan dan Perkembangan Anak}

Proses pertumbuhan dan perkembangan seorang anak sangat bervariasi, baik itu dari segi fisik maupun mental, tergantung dari faktor-faktor yang memengaruhi dan mendukung yang ada di sekitarnya. Menurut Widyastuti \& Widyani (Google-book, diakses pada Agustus 2012) ada dua faktor utama yang memengaruhi tumbuh kembang seorang anak, yaitu faktor genetik dan faktor lingkungan. Faktor genetik ditentukan oleh faktor keturunan (gen) yang diwariskan orangtua kepada anaknya. Bila orangtua bertubuh besar, maka akan memiliki anak yang menyerupai dirinya, begitu pula sebaliknya. Sedangkan faktor lingkungan adalah faktor eksternal yang ikut memengaruhi tumbuh kembang anak, yang terdiri dari: tempat tinggal, lingkungan pergaulan, sinar matahari yang diterima, status gizi, tingkat kesehatan orangtua, tingkat emosi dan latihan fisik.

Seorang anak yang tinggal di tempat tinggal yang udaranya segar (cukup oksigen) dapat melakukan pembakaran yang lebih baik dengan anak yang tinggal di tempat yang udaranya penuh dengan polusi. Hal tersebut menjadi salah satu contoh betapa pentingnya tempat tinggal bagi pertumbuhan dan perkembangan seorang anak. Demikian pula dengan lingkungan pergaulan anak, dalam hal ini, yang dimaksud adalah orangtua serta anggota keluarga lain, termasuk juga tetangga. Apabila seorang anak bertemu dan bergaul dengan orang-orang yang penuh kehangatan, cinta kasih, mesra, suasana tersebut mendukung anak untuk tumbuh dan berkembang secara optimal, demikian pula sebaliknya. Seperti diketahui bahwa sinar matahari berhubungan erat dengan proses pembentukan vitamin D untuk pertumbuhan tulang dan gigi. Bila seorang anak mendapatkan sinar matahari yang cukup, pertumbuhan tulangnya dapat optimal. Namun, jika anak menerima kelebihan maupun kekurangan, hal itu dapat berakibat kurang baik pada anak. Hal lain yang juga sangat memengaruhi tumbuh kembang anak adalah status gizinya. Jika anak mendapatkan asupan gizi yang cukup dan seimbang, baik kualitas maupun kuantitasnya, ia akan mendapatkan juga energi yang cukup untuk tumbuh kembang yang baik. Tingkat kesehatan orangtua juga ikut memengaruhi tumbung kembang anak. Bayi yang dilahirkan dari pasangan suami istri yang sehat, maka dapat tumbuh dan berkembang secara optimal karena cukupnya gizi yang diperlukan untuk proses tersebut. Hal terakhir adalah tingkat emosi dan latihan fisik. Anak pada dasarnya memiliki temperamen yang berbeda-beda. Orangtua perlu memerhatikan hal tersebut sehingga tingkat emosi sang anak dapat ditangkap secara tepat, dan selanjutnya mengupayakan agar mereka merasa nyaman. Latihan fisik juga perlu diterapkan, seperti misalnya pijat bayi agar otot-otot dan tulang anak dapat terangsang untuk berfungsi secara optimal.

Hal yang sama juga diungkapkan oleh Soetjiningsih (1995), bahwa faktor pertumbuhan dan perkembangan anak dipengaruhi oleh dua faktor utama, yaitu faktor keturunan dan lingkungan. Namun beliau menambahkan lebih detail lagi pada faktor lingkungan, yang dibagi menjadi pranatal (lingkungan pada waktu anak masih dalam kandungan) dan prenatal (lingkungan setelah anak dilahirkan). Dikemukakan lebih lanjut oleh penulis bahwa faktor lingkungan pranatal terdiri dari gizi ibu pada waktu hamil, faktor mekanis, toksin/zat kimia, endokrin, radiasi, infeksi, stres, imunitas, dan anoreksia embrio. Sedangkan faktor lingkungan post-natal adalah lingkungan biologis (ras/suku bangsa, jenis kelamin, umur, gizi, perawatan kesehatan, kepekaan terhadap penyakit, penyakit kronis, fungsi metabolisme, dan hormon), faktor fisik (cuaca/musim/keadaan geografis suatu daerah, sanitasi, keadaan rumah, dan radiasi), faktor psikososial (stimulasi, motivasi belajar, ganjaran atau hukuman yang wajar, kelompok sebaya, stres, sekolah, cinta dan kasih sayang, serta kualitas interaksi anakorangtua), dan faktor keluarga dan adat istiadat (seperti: pekerjaan/pendapatan keluarga, pendidikan ayah/ibu, jumlah saudara, jenis kelamin dalam keluarga, stabilitas rumah tangga, kepribadian ayahibu, adat-istiadat/norma-norma/tabu, agama, urbanisasi, dan kehidupan politik dalam masyarakat). 
Begitu kompleksnya hal-hal yang memengaruhi tumbung kembang anak, dapat dilihat dari gambar berikut.

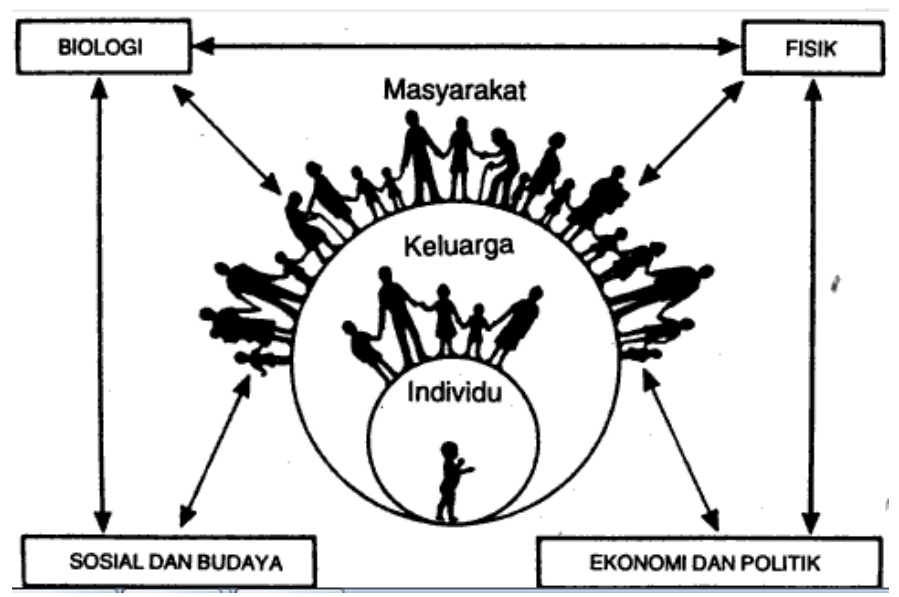

Gambar 2 Pengaruh Lingkungan terhadap Tumbuh-Kembang Anak Sumber: Ebrahim (dalam Soetjiningsih, 1995: 11)

\section{METODE PENELITIAN}

Penelitian ini menggunakan pendekatan kualitatif, terutama untuk mengkaji bagaimana pesan dalam iklan ditandakan dan disampaikan. Oleh karenanya, penelitian ini menggunakan metode analisis semiotika untuk mengungkap tanda-tanda yang ada dalam objek kajian peneliti yaitu iklan susu formula balita SGM Eksplor Presinutri 3. Unit analisis yang akan diteliti adalah teks-teks yang muncul dalam iklan tersebut, baik berupa gambar, suara (kata-kata) ataupun tulisan.

\section{HASIL DAN PEMBAHASAN}

\section{Setting dan Penggalan Adegan dalam Iklan}

Dalam analisis semiotika dan kajian budaya diketahui bahwa tidak ada satu makna yang bersifat netral dan bisa dipaksakan kepada penerima pesan (Sobur, 2003: 4). Tujuan analisis semiotik adalah menempatkan tanda pada konteks yang sesuai dengan interpretan. Dengan demikian analisis ini juga mengandaikan aspek-aspek demografis seperti gender, ras, dan kelas, serta aspek-aspek personal seperti “self', relasi peran, dan keanggotaan kelompok (Bluer, 1969 dalam Denzin \& Lincoln, 2009: $623)$.

Menurut Winfried Noth (dalam Sobur, 2002: 133), kajian iklan dapat dipandang sebagai proses semiosis, yaitu suatu proses yang membuat suatu tanda berfungsi sebagai tanda yang mewakili apa yang ditandainya. Proses semiosis ini dapat berjalan melalui beberapa tingkatan seperti apa yang diuraikan oleh Hoed (dalam Sobur, 2002: 134). Beberapa adegan yang dapat dilihat dalam iklan susu formula SGM Eksplor Presinutri 3 antara lain dapat dijabarkan sebagai berikut.

Setting iklan berada dalam ruangan (indoor) yang memperlihatkan seorang ibu dengan anak balitanya yang berumur dua tahun sedang menerima kunjungan tamu yaitu tiga orang ibu di rumahnya. 
Warna yang dominan dalam iklan ini adalah putih, yang memperlihatkan kebersihan, keterbukaan, kemurnian dan kesan ruang yang lapang (Onkvisit \& Shaw, 2009: 215), terlihat dari warna furnitur, dinding, rak tempat simpan susu, baju beberapa ibu, dan warna baju anak. Warna putih ini dikombinasikan dengan warna merah, yang merupakan representasi dari produk susu tersebut. Warna merah ini dapat dilihat dari kemasan kardus susu, bantalan kursi, warna minuman, dan juga kancing baju anak. Menurut suatu penelitian, salah satu kombinasi warna yang dapat meningkatkan kesuksesan iklan adalah merah dan putih (Onkvisit \& Shaw, 2009: 215). Kemudian gambar menunjukkan seorang anak balita berumur dua tahun memakai dan mengancingkan sendiri bajunya, dengan fokus pada kancing yang berwarna merah. Lalu terlihat tiga orang ibu yang bertamu kagum terhadap kemampuan si balita dengan mengungkapkan kalimat "wah baru dua tahun kok bisa ya...". Terdengar backsound yang menggambarkan isi pikiran yang ada pada ibu-ibu, "rahasianya pasti vitaminnya deh.." dan "susunya pasti mahal...", dan kemudian si anak balita digambarkan dapat membawa minuman berwarna merah untuk disuguhkan ke ibu-ibu yang sedang terheran-heran. Baru kemudian muncul gambar si ibu balita membuka rak dan terdapatlah satu kardus kemasan susu berwarna merah dengan merek SGM Eksplor Presinutri 3, dan kemudian terlihat ibu-ibu tersebut paham dan mengatakan "ohh SGM eksplor rahasianya”. Penggalan iklan berikutnya adalah berupa penjelasan tentang kandungan presinutri yang ada dalam susu kemasan tersebut dengan kalimat selanjutnya "agar si kecil selalu meraih prestasi”.

\section{Tanda Iklan Susu SGM Eksplor Presinutri 3 Menurut Model Semiotika Peirce}

Deretan pesan yang disampaikan di atas terdiri atas banyak tanda yang bisa diamati. Didalamnya kita dapat menyimpulkan banyak makna. Berdasarkan model semiotika Peirce dan menggunakan proses semiosis, maka peneliti dapat menyampaikan secara singkat sebagai berikut:

\section{Proses Pertama}

Tanda I : Anak

Objek I : sosok anak balita berumur dua tahun

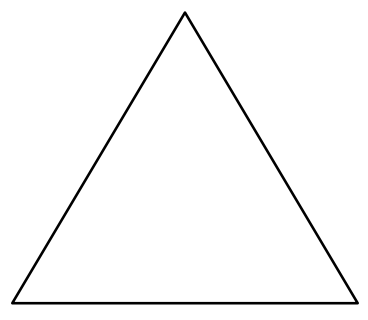

Interpretant I : Anak balita berumur dua tahun sudah dapat memakai baju sendiri (pintar dan aktif) dengan kancing baju berwarna merah

\section{Proses Kedua}

Tanda II : Anak pintar dan aktif

Objek II : anak balita pintar dan aktif menandakan ada bahan makanan yang membuatnya pintar dan aktif

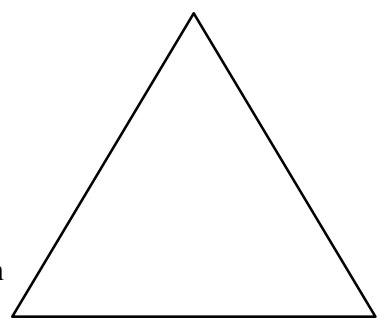

Interpretant II : anak balita pintar dan aktif pasti meminum vitamin dan susunya mahal 


\section{Proses Ketiga}

Tanda III : susu yang diminum

balita pintar

Objek III : sebuah kemasan susu berwarna merah yang diminum oleh si balita

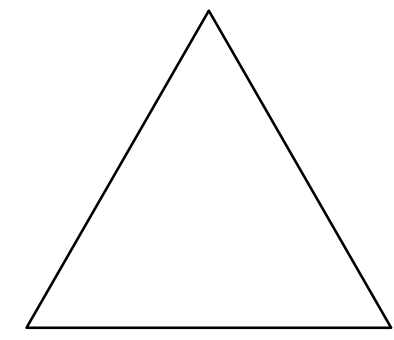

Interpretant III : susu tersebut bernama SGM eksplor presinutri 3

\section{Proses Keempat}

Objek IV : susu yang mengandung nutrisi yang presisi/tepat untuk balita
Tanda IV : susu SGM eksplor yang mengandung presinutri

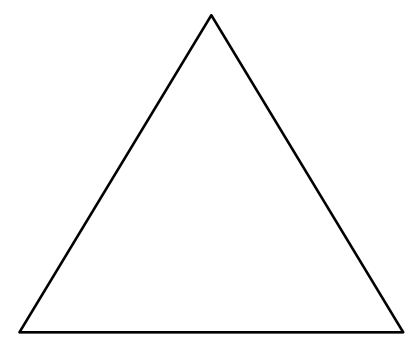

Interpretant IV : kandungan nutrisi dan komposisi yang tepat membuat balita 2 tahun bisa berprestasi

Dari uraian di atas dapat dilihat bahwa tanda-tanda dalam teks iklan di atas telah dibentuk dan dikonstruksi sedemikian rupa untuk dapat dimaknai oleh pembaca iklan televisi. Sistem tanda tidak hanya terdiri atas kalimat dan uraian saja tetapi semua elemen tanda berperan secara bersama-sama untuk menanamkan makna terhadap pembacanya. Elemen tanda yang disampaikan dalam iklan tersebut antara lain disampaikan melalui bahasa lisan, tulisan dan gambar, termasuk di dalamnya pemakaian warna merah sebagai simbol kemasan produk. Untuk melihat sistem tanda yang terdiri dari ikon, indeks, dan simbol, maka dapat diuraikan sebagai berikut.

\section{Tabel 1 Sistem Tanda}

\begin{tabular}{|c|c|c|c|}
\hline No & Ikon & Indeks & Simbols \\
\hline & $\begin{array}{l}\text { Warna merah yang terdapat pada } \\
\text { kancing, bantalan kursi, warna } \\
\text { minuman }\end{array}$ & $\begin{array}{l}\text { Warna yang ada pada kemasan susu } \\
\text { SGM eksplor presinutri } 3\end{array}$ & $\begin{array}{l}\text { Makna yang ditanamkan pada } \\
\text { pemirsa untuk mengingat warna } \\
\text { merah sebagai warna dominan } \\
\text { kemasan susu SGM eksplor } \\
\text { presinutri } 3\end{array}$ \\
\hline & Anak balita 2 tahun & Gerak-gerik anak balita umur 2 tahun & $\begin{array}{l}\text { Diucapkan kata } 2 \text { tahun oleh } \\
\text { seorang ibu yang kagum “wah, } \\
\text { baru } 2 \text { tahun kok bisa ya...” }\end{array}$ \\
\hline & $\begin{array}{l}\text { Anak balita } 2 \text { tahun yang } \\
\text { berprestasi }\end{array}$ & $\begin{array}{l}\text { Gerakan motorik yang melambangkan } \\
\text { prestasi anak umur } 2 \text { tahun yaitu dapat } \\
\text { mengancingkan baju sendiri }\end{array}$ & $\begin{array}{l}\text { Diucapkan oleh ibu yang } \\
\text { kagum dengan kemampuan } \\
\text { motorik anak balita } 2 \text { tahun } \\
\text { "wah baru } 2 \text { tahun kok bisa } \\
\text { ya...” }\end{array}$ \\
\hline & $\begin{array}{l}\text { Gambar kandungan nutrisi pada } \\
\text { susu SGM eksplor presinutri } 3\end{array}$ & $\begin{array}{l}\text { Bahwa susu ini mengandung nutrisi } \\
\text { yang disebutkan }\end{array}$ & $\begin{array}{l}\text { Nutrisi-nutrisi yang terkandung } \\
\text { dalam susu SGM eksplor dapat } \\
\text { membuat anak berprestasi }\end{array}$ \\
\hline
\end{tabular}




\section{Representasi Pertumbuhan dan Perkembangan Anak yang Optimal}

Beberapa informasi dalam iklan menggiring pembacanya untuk percaya bahwa dengan mengonsumsi susu tersebut, maka anak balita dapat dipastikan akan menjadi anak yang pintar dan berprestasi. Terdapat penggambaran bahwa anak balita berumur dua tahun yang tersebut dalam iklan sudah dapat melakukan kegiatan motorik dengan baik dan ini ternyata dikarenakan balita tersebut meminum produk susu yang diiklankan. Terlihat dari kemampuan anak memasang kancing baju sendiri (yang menjadi fokus prestasi/ kemampuan motorik halus anak), membantu ibu membawa minuman untuk disuguhkan kepada para tamu, bersalaman dengan para tamu, dan juga tidak antisosial.

Suatu asosiasi umum yaitu anak pintar pasti karena mengonsumsi susu mahal (terlihat dari pemikiran salah seorang tamu yang berkata dalam hati dan membayangkan merek kompetitor - dilihat dari warna yang diperlihatkan, yaitu emas, biru dan putih - yang secara pasti harganya lebih mahal dari susu SGM). Maka produser menyampaikan pesan dalam iklan ini bahwa untuk mendapatkan nutrisi dengan komposisi yang tepat dan dibutuhkan anak, tidak selalu atau tidak semestinya membeli susu yang mahal harganya. Jadi harga susu yang lebih murah tidak selalu berarti kualitasnya lebih rendah daripada merek lain yang lebih mahal harganya.

Pendekatan iklan ini mengandung unsur baik informational/rational appeals dan juga emotional. Unsur informational/rational appeals dapat dilihat dari harga produk yang ditawarkan relatif lebih murah, manfaat yang dapat dirasakan untuk anak-anak balita, competitive advantage dari kandungan nutrisi yang tepat dan didukung oleh penelitian yang valid. Dari segi emotional appeals, para konsumen disodorkan dengan karakter dalam iklan anak balita yang sehat, pintar dan menggemaskan, sehingga dapat membangkitkan keinginan orangtua, khususnya ibu-ibu, untuk memiliki anak balita yang seperti itu. Hal tersebut juga memberikan perasaan positif kepada konsumen yang ditransfer kepada merek tersebut. Iklan ini ingin membangkitkan perasaan senang, bangga dan ingin agar anak balita mencapai prestasi seoptimal mungkin.

Meskipun banyak yang meyakini bahwa meminum susu bukanlah satu-satunya faktor yang menjadikan anak balita akan berkembang menjadi anak yang pintar dan berprestasi, tetapi iklan susu ini telah menggiring pembacanya melalui tanda yang disampaikan, untuk memercayai bahwa produk susu ini merupakan rahasia bagi para ibu-ibu yang menginginkan anak balitanya tumbuh pintar dan berprestasi.

\section{SIMPULAN}

Memaknai sebuah iklan di televisi dapat dilakukan dengan membaca teks-teks yang disampaikan di dalamnya. Sistem tanda yang terdapat dalam iklan susu formula SGM Eksplor Presinutri 3 telah menunjukkan bahwa tanda-tanda yang terdapat dalam iklan tersebut penuh dengan ikon-ikon dan simbol-simbol yang dapat dimaknai oleh ibu-ibu yang memiliki anak balita agar memilih susu tersebut bila menginginkan anak balitanya tumbuh pintar dan berprestasi. Setiap tanda dalam iklan tersebut dibangun secara bertahap dan setiap tanda baik visual, audio visual dan tekstual untuk mendekati pembacanya, yang akhirnya memberikan interpretasi kepada pembaca bahwa rahasia memiliki anak yang tumbuh berprestasi adalah dengan meminum susu tersebut. 


\section{DAFTAR PUSTAKA}

Belch, G. E. \& Belch, M. A. (2009). Advertising and Promotion: An Integrated Marketing Communications Perspective (8th ed). New York: McGraw-Hill.

Berger, A. A. (2005). Tanda-Tanda dalam Kebudayaan Kontemporer, Suatu Pengantar Semiotika. Yogyakarta: Tiara Wacana Yogya.

Denzin, N. K. \& Lincoln, Y. S. (2009). Handbook of Qualitative Research. Yogyakarta:

Holmes, H. K. (2005). Advertising as Multilingual Communication. New York: Palgrave Macmillan.

Johansen, J. D. \& Larsen, S.E. (2002). Sign in Use, an Introduction to Semiotics. London: Routledge.

Onkvisit, S. \& Shaw, J. J. (2009). International Marketing: Strategy and Theory (5th ed). New York: Routledge.

Pustaka Pelajar.

Sobur, A. (2003). Semiotika Komunikasi. Bandung: Remaja Rosdakarya.

Soetjiningsih, -. (1995). Tumbuh Kembang Anak. Penerbit Buku Kedokteran EGC: Jakarta. Googlebook, di akses pada 1 Agustus 2012 http://books.google.co.id/books?id=JBtl87roMJIC\&p $\mathrm{g}=$ PA2\&lpg=PA2\&dq=faktor+tumbuh+kembang+anak\&source=bl\&ots=CKGo2DCepW\&sig =zupSA0M5aX5xZINfC0HQlcibQdY\&hl=en\&sa=X\&ei=2mcjUJbOoayrAewwIGYCg\&ved=0CDoQ6AEwAQ

Straubhaar \& La Rose. (2004). Media Now, Understanding media, Culture, and Technology (4th ed). USA: Wadsworth/Thomson Learning.

Widyastuti, D. Rr. \& Widyani, R. Rr. Panduan Perkembangan Anak 0-1 tahun. Puspa-Swara: Cimanggis, Jawa Barat. Google-book, di akses pada 1 Agustus 2012 http://books.google.co.id/books?id=E67c-

No_IdQC\&pg=PR7\&lpg=PR7\&dq=faktor+tumbuh+kembang+anak\&source=bl\&ots=XBSxd Tp2gh\&sig=qNNIWkue1ZFVNQm4jHCSKQaJ4SY\&hl=en\&sa=X\&ei=2mcjUJbOoayrAewwIGYCg\&ved=0CEMQ6AEwAw\#v=onepage\&q=faktor\%20tumbuh\%20kemban $\mathrm{g} \% 20 \mathrm{anak} \& \mathrm{f}=$ false 